\title{
TESTING ASSUMPTIONS OF THE "SLIPPERY SLOPE FRAMEWORK” USING CROSS-COUNTRY DATA: EVIDENCE FROM SUB-SAHARAN AFRICA
}

\author{
Abdulsalam Mas'ud \\ Hussaini Adamu Federal Polytechnic \\ Nor Aziah Abd Manaf \\ Universiti Utara Malaysia \\ Natrah Saad \\ Universiti Utara Malaysia
}

\begin{abstract}
The emergence of "Slippery Slope Framework" has attracted many researchers who examined the effect of trust in authorities and power of authorities on tax compliance using both the real taxpayer and student subjects. However, these researchers have neglected the use of crosscountry data to examine these effects. In line with prior empirical evidences that confirm the effect of trust and power of authorities on tax compliance, this study hypothesizes that both trust and power have association with tax compliance across countries. It further hypothesizes that trust has more association with tax compliance than power. This study is based on $49 \mathrm{Sub}-$ Saharan African countries as the population, out of which 37 countries were selected using multi-stage random sampling. The empirical results from these countries reveal that there is an association between both trust in authorities and power of authorities and tax compliance across the 37 Sub-Saharan African countries, but the association between power of authorities and tax compliance is stronger than that of trust in authorities and tax compliance. Further, the result does not find any causing effect of both trust and power on tax compliance in the countries that constituted the study sample.
\end{abstract}

Keywords: Authorities; Compliance; Power; Tax; Trust.

\section{INTRODUCTION}

Though "deterrence models" proposed by Allingham and Sandmo (1972) and Srinivasan (1973) have failed to fully explain why individuals pay taxes, they still remain significant in tax compliance research. The concept of "psychological tax contract" proposed by Feld and Frey (2007) and Torgler, Demir, Macintyre and Schaffner (2008) have also contributed to understanding why individuals pay taxes without enforcement. The combination of these efforts provides a robust framework known as the "Slippery Slope Framework" by Kirchler,

2 Corresponding author: Department of Accountancy, Hussaini Adamu Federal Polytechnic, Jigawa State - Nigeria. Email: masudabdussalam@yahoo.com; Tel: +60166839255,+2347036824625. 
Hoelzl and Wahl (2008) which to a certain extent, explains why people pay taxes with or without enforcement, i.e., either through trust in authorities leading to voluntary tax compliance or through power of authorities leading to enforced tax compliance. Since the emergence of the Slippery Slope Framework, studies have been conducted to test the effect of trust and power to explain compliance behavior using real taxpayers and students simulations. However, analyses have not yet been using cross-country data. Therefore, this study aims to examine the effect of trust and power using African cross-country data generated from difference sources.

The second part of the paper provides a conceptual framework and review of previous empirical analyses relating to the effect of trust and power on tax compliance. The third part deals with the methodology used to conduct the study. The fourth part presents the results and analysis. Finally, a conclusion is drawn.

\section{CONCEPT OF TAX COMPLIANCE BEHAVIOR}

Tax compliance has been divided into two perspectives: administrative compliance, i.e., adherence to applicable tax laws; and judicious compliance in terms of accurate completion of tax returns (Chow, 2004). Regardless of its type, tax compliance has been defined as reporting to the relevant tax authority all income and tax payments using the applicable tax laws and regulations as well as court orders (Jackson \& Milliron, 1986). It can also be defined as an individual's act of filing tax returns, declaring all income accurately for tax purposes and paying tax liabilities on the due dates as stipulated by the authority or applicable tax laws (Palil \& Mustapha, 2011). Similarly, voluntary tax compliance has been defined as "timely filing and reporting of required tax information, the correct self-assessment of taxes owed and the timely payment of those taxes without enforcement action" (Silvani \& Baer, 1997, p. 11). Under voluntary tax compliance, taxpayers have to assess themselves using correct information in a timely manner, report the tax due, file the tax returns with the relevant tax authority and make timely payment of the tax payable, usually to designated banks. However, enforced compliance refers to a situation where taxpayers will only be willing to comply with their tax obligations either due to fear of being detected or audited.

The issue of tax and tax compliance behavior is as old as mankind (Ramona-Anca \& LarissaMargareta, 2012). People naturally do not want to pay taxes; however, in this world, two things are inevitable, i.e., death and taxes (Alm, 1999). This inherent hatred to pay taxes has therefore resulted in authorities being very concerned about tax compliance behavior. This has led to researchers widely studying the effect of tax evasion and noncompliance. Noncompliance comprises two categories: intentional and unintentional. Intentional noncompliance is caused by tax evasion; while unintentional non-compliance is caused by the taxpayers' lack of knowledge or ignorance of tax laws or financial condition (Loo, 2006).

The issue of tax noncompliance is a global phenomenon that governments in both developed and developing nations have to deal with. For instance, the amount of unpaid income taxes for individuals and corporations was about USD 127 billion for the 1992 tax year in the United States (US) (Alm, 1999). Recently, tax evasion in the US averages USD 285 billion annually (Cobham, 2005). More recently, in 2011, the unpaid taxes amounted to USD 373 
billion (Government Accountability Office, 2012). In developing countries, statistics estimate the average tax evasion in 2002 as being between 35 and 55\% of the Gross Domestic Product (GDP), which is worse than that of developed nations, like the US (Terkper, 2003). In 2011, tax revenues accounted for more than $33 \%$ of the GDP in developed countries compared to less than 20\% in African countries (Carter \& Cebreiro, 2011).

In addition, about $95 \%$ of personal income taxes in developing countries come from the formal sector through withholding tax, particularly Pay As You Earn (PAYE), of which tax was deducted by the public sector and large firms from the salaries and wages of their employees, compared to 80\% in developed nations (International Monetary Fund, 2011, p. 31). International Monetary Fund further states that less than $5 \%$ of the population in developing countries pays personal income tax compared to about 50\% in developed nations. Further, only about $15 \%$ of taxpayers' incomes are reached for tax purposes compared to about $57 \%$ in developed countries. A comparison of personal income tax as a percentage of GDP reveals that for the period of $1980-2005$, personal income tax was $9-11 \%$ of GDP in developed countries compared to less than $2 \%$ in developing countries (Sabirianova, Buttrick, \& Duncan, 2009, pp. 24-25). Therefore, tax compliance behavior will continue to be an area of research in both developed and developing countries in years to come.

\subsection{The Slippery Slope Framework Concept}

The Slippery Slope Framework for tax compliance behavior was developed by Kirchler, et al. (2008) through conceptual analysis. The Framework shows the need to consider the power and trust in authorities and their forceful interaction for a better understanding of tax compliance behavior. The Framework highlights how power and trust play important roles in both enforced and voluntary tax compliance, respectively. Figure 1 below is the schematic representation of the Framework.

Figure 1: The Slippery Slope Framework

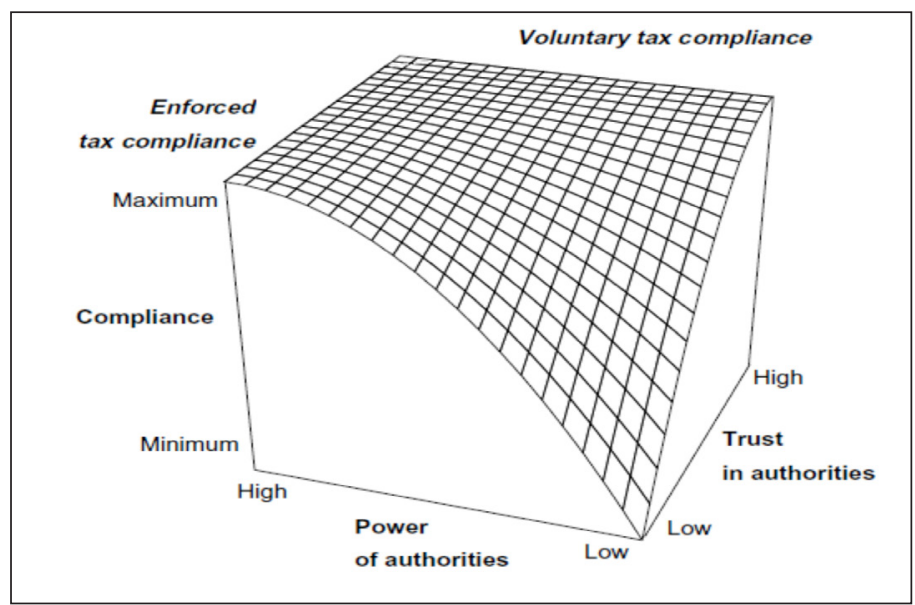

Source: Kirchler, Hoelzl and Wahl (2008: p 212) 
Power of authorities means taxpayers' perception of the ability of tax officers to detect illegal tax noncompliance. This can be through rigorous audit to detect the evasion and authorities' power to fine the evaders. Trust in authorities means the general opinion of taxpayers and social groups that the tax authorities are compassionate, work beneficially for the common good of the citizens, ensure good governance and are not corrupt. Kirchler, et al. (2008) assert that both trust and power interact to explain tax compliance. Hence, if taxpayers perceive that tax authorities are powerful and trustworthy, the result would be high compliance, and vice versa.

\subsection{Prior Empirical Analysis of the Slippery Slope Framework}

To further prove the assumption of the Slippery Slope Framework, Wahl, Kastlunger and Kirchler (2010) provided the first empirical analysis of the main hypotheses of the "Slippery Slope Framework". The Framework's assumption is that both trust in authorities and power of authorities increase tax compliance. The study was conducted through two experiments. Experiment 1 (students) examined the effect of voluntary compliance and enforced compliance on the overall tax compliance with mediating effect of trust and power, respectively. The two independent variables of voluntary and enforced compliance were jointly moderated by age, gender and income (demographic variable). Experiment 2 (self-employed) examined the effect of intended tax payment, voluntary tax payment, enforced tax payment and strategic tax payment on overall tax payment through the moderating effect of age, gender and income. A quantitative research paradigm was employed with 124 students in Experiment 1and 186 selfemployed in Experiment 2. Computer aided programmed with z-tree was used in Experiment 1; whereas Experiment 2 used questionnaires sent to the email addresses of the subjects. Data of Experiment 1 was analyzed using descriptive statistics with 2-way MANCOVA and ANCOVA; while Experiment 2 used descriptive statistics with 2-way ANCOVA. The results showed that voluntary compliance is high when the authorities are trustworthy.

Researchers have continued to test the Slippery Slope Framework assumptions globally. Kastlunger, Lozza, Kirchler and Schabmann (2013) investigated the assumptions of the Slippery Slope Framework through model testing and enhanced the existing evidence on the framework by distinguishing coercive power from legitimate power. The study correlated tax evasion with enforced tax compliance, voluntary tax compliance, legitimate power, coercive power and trust. Quantitative research paradigm was employed with 389 Italian subjects as sample. Data was collected through online and mail surveys. Structural Equation Modeling was used to analyze the data. The result showed that trust enhanced voluntary tax compliance and voluntary tax compliance itself is negatively related to tax evasion. Accordingly, it confirms the assumption of the Slippery Slope Framework that coercive power affects enforced tax compliance. Further, the result showed that both voluntary and enforced compliance, as well as trust and coercive power, are negatively related.

Kogler et al. (2012) tested the main assumptions of the Slippery Slope Framework in four European countries. The research measured how the four variables of intended tax compliance, voluntary tax compliance, enforced tax compliance and strategic tax compliance mediate the relationship between tax compliance and the independent variables of trust, power and 
country. Experimental quantitative research design was employed on 1,319 students from four universities in the four countries under the study. Data was collected through the survey method using questionnaires and analyzed using three way MANOVA descriptive statistics. Results showed strong effect of trust and power separately on compliance. A joint effect of trust and power on tax compliance was also found. There was also a weak effect of trust, power and country on tax compliance. A strong effect was found on trust and country as well as power and country.

In another research, Pellizzari and Rizzi (2014) presented a model with heterogeneous agents who maximize their individual utility based on income (after-tax) and the conjectured level of per capita public expenditure. This was an extension of the Slippery Slope Framework. They studied the relationship between tax compliance as a dependent variable with citizenship (perception of public expenditure, peer influence, risk aversion, morality) and power as independent variables. Experimental research design was employed based on 250 simulations. Data was analyzed using descriptive statistics. The results showed that both citizenship and power are required for tax compliance. But citizenship has more influence on compliance than power. The study extended one part of the slippery slope framework (trust) by adding more dimension to it, thereby changing the variable name citizenship.

From the foregoing, it is evident that several scholars have tested the assumptions of the Slippery Slope Framework in various countries using different subjects and simulations. The findings of these studies indicate that trust and power interact to explain the compliance behavior of taxpayers. However, none of the studies has examined the effect of trust and power on tax compliance using cross-country data. Therefore, this study intends to examine this assumption so as to provide more evidence using a different research dimension, based on the following hypotheses from a cross-country perspective:

H1 Trust in Authorities has a significantly positive correlation with tax compliance H2 Power of Authorities has a significantly positive correlation with tax compliance H3 Trust has a more significantly positive correlation with tax compliance than power H4 Trust and Power explain tax compliance (causing effect)

\section{METHODOLOGY}

This section discusses the methodology and methods used in conducting the study, as well as the population, sample, variables, measurement, data and the research model.

\subsection{Population and Sample}

The population of the study is 49 Sub-Saharan African countries as contained in the World Bank Group-WBG (2012). A sample of 37 countries was selected using multi-stage sampling technique. In the first stage, countries were selected based on the availability of data on the three variables of the study; nine countries were dropped due to lack of complete data for all the three variables, leaving 40 countries. In the second stage, three countries were found to be outliers when power and trust were tested individually against tax compliance, leaving a final sample of 37 countries. 


\subsection{Variables and Variable Measurement}

For tax compliance (TC), tax as a percentage of GDP for all the countries was used. We generated scores of 1-10 for this data by dividing tax as a percentage of GDP by 100 and multiplying by 10 . This approach was similar to that reported by the IMD index and disclosed in $\operatorname{Kim}(2008$, p. 407). For instance, tax as a percentage of GDP for Norway and Denmark is $57 \%$ and $55.9 \%$, respectively; and their tax evasion scores as reported by IMD are 5.67 and 5.43 , respectively. This depicts some level of consistencies between tax as a percentage of GDP and tax evasion scores of IMD. The interpretation of the IMD is that the higher the score, the lower the evasion (higher compliance). Similarly, in our tax compliance score, the higher the score, the higher the compliance (lower evasion).

For trust (TRUST), we used Transparency International's (TI) Corruption Perception Index (CPI) as a proxy of trust. Similar studies on cross-country analysis (Kastlunger, et al., 2013; Torgler, Schaffner, \& Macintyre, 2007; Torgler \& Schneider, 2009) have used the same as proxy of trust. TI measured CPI on class intervals (high corruption 0-9; 10-19; 20-29; 30-39; $40-49$; 50-59; 60-69; 70-79; 80-89; 90 -100 low corruption).

For power (POWER), we used the rule of law as a proxy based on the definition of the WBG in Worldwide Governance Indicators (WGI). The study used the same proxy to compare Austria with other European countries in terms of power of authorities. The rule of law, as defined in the WGI is based on Kaufmann, Kraay, and Mastruzzi's (2010) methodology. It is based on percentile of power (low power 0-10th; 11-20th; 21-30th; 31- 40th; 41-50th; 51-60th; 61-70th; 71-80th; 81-90th; 91-100th high power).

\subsection{Data and Data Analysis}

The data was obtained from different sources. Data relating to tax as a percentage of GDP was sourced from the US Central Intelligence Agency (CIA) database for the year 2012 (Central Intelligence Agency, 2012). The rule of law was sourced from the WBG report for the year 2012 (World Bank Group, 2012). Lastly, CPI was sourced from the TI report for the year 2012 (Transparency International, 2012). Data was analyzed using SPSS version 19. The data is presented in Table 1 below:

\subsection{Research Model}

From these three variables we developed a model:

$T C_{i}=\beta_{0}+\beta_{1} \operatorname{TRUST}_{i}+\beta_{2} \mathrm{POWER}_{i}+\mu_{i}$

where $T C_{i}$ is tax compliance rating for a country; $\beta_{0}$ constant; TRUST is the trust in authorities; POWER is power of authorities; and $\mu$ the error term. 
Table 1: Tax as Percentage of GDP and Tax Evasion Scores of African Countries

\begin{tabular}{|c|c|c|c|c|c|}
\hline $\mathbf{S} / \mathbf{N}$ & Country & $\begin{array}{c}\text { Tax as \% } \\
\text { of GDP } \\
\text { (CIA, 2012) }\end{array}$ & $\begin{array}{c}\text { Tax } \\
\text { Compliance } \\
\text { Scores }\end{array}$ & $\begin{array}{c}\text { Rule of } \\
\text { Law (WBG, } \\
\text { 2012) }\end{array}$ & $\begin{array}{c}\text { Corruption } \\
\text { Perception } \\
\text { (TI, 2012) }\end{array}$ \\
\hline 1 & Sao Tome and Prin. & 39.9 & 3.99 & 28.2 & 42 \\
\hline 2 & Swaziland & 38.7 & 3.87 & 42.3 & 37 \\
\hline 3 & Equatorial Guinea & 37.4 & 3.74 & 11.3 & 20 \\
\hline 4 & Namibia & 36.8 & 3.68 & 61.0 & 48 \\
\hline 5 & Botswana & 31.3 & 3.13 & 69.5 & 65 \\
\hline 6 & Mozambique & 29.6 & 2.96 & 33.8 & 32 \\
\hline 7 & Congo, Dem. Rep., & 28.3 & 2.83 & 1.9 & 21 \\
\hline 8 & Liberia & 27.8 & 2.78 & 17.8 & 41 \\
\hline 9 & Mauritania & 27.2 & 2.72 & 21.1 & 31 \\
\hline 10 & Gabon & 27.1 & 2.71 & 38.0 & 35 \\
\hline 11 & Eritrea & 26.1 & 2.61 & 7.5 & 26 \\
\hline 12 & South Africa & 25.9 & 2.59 & 58.7 & 43 \\
\hline 13 & Niger & 25.8 & 2.58 & 37.1 & 33 \\
\hline 14 & Chad & 25.4 & 2.54 & 3.8 & 19 \\
\hline 15 & Senegal & 24.2 & 2.42 & 40.4 & 36 \\
\hline 16 & Ghana & 23.8 & 2.38 & 54.5 & 45 \\
\hline 17 & Guinea & 23.6 & 2.36 & 3.3 & 24 \\
\hline 18 & Rwanda & 23.1 & 2.31 & 46.9 & 53 \\
\hline 19 & Cape Verde & 22.9 & 2.29 & 63.8 & 60 \\
\hline 20 & Burkina Faso & 21.9 & 2.19 & 44.6 & 38 \\
\hline 21 & Togo & 20.7 & 2.07 & 23.5 & 30 \\
\hline 22 & Zambia & 20.7 & 2.07 & 39.4 & 37 \\
\hline 23 & Cote d'Ivoire & 20.3 & 2.03 & 8.0 & 29 \\
\hline 24 & Tanzania & 19.7 & 1.97 & 34.3 & 35 \\
\hline 25 & Gambia, The & 19.7 & 1.97 & 54.5 & 34 \\
\hline 26 & Cameroon & 19.0 & 1.90 & 16.0 & 26 \\
\hline 27 & Benin & 18.9 & 1.89 & 27.2 & 36 \\
\hline 28 & Kenya & 18.0 & 1.80 & 16.4 & 27 \\
\hline 29 & Mali & 17.6 & 1.76 & 35.7 & 34 \\
\hline 30 & Madagascar & 17.4 & 1.74 & 23.9 & 32 \\
\hline 31 & Central African Rep. & 15.7 & 1.57 & 7.0 & 26 \\
\hline 32 & Ethiopia & 15.2 & 1.52 & 29.1 & 33 \\
\hline 33 & Uganda & 14.8 & 1.48 & 43.7 & 29 \\
\hline 34 & Guinea-Bissau & 14.8 & 1.48 & 6.1 & 25 \\
\hline 35 & Sierra Leone & 13.5 & 1.35 & 22.5 & 31 \\
\hline 36 & Nigeria & 8.3 & 0.83 & 9.9 & 27 \\
\hline 37 & Sudan & 6.6 & 0.66 & 2.8 & 13 \\
\hline
\end{tabular}

Note: $\mathrm{n}=37$ 


\section{RESULT AND DISCUSSIONS}

Table 2 depicts the descriptive statistics of the three variables of the study. Table 3 presents Pearson correlations among the variables. Table 4 presents the regression analysis on the effect of trust and power on tax compliance. The results are depicted below.

Table 2: Descriptive Statistics

\begin{tabular}{cccccc}
\hline Variables & N & Mean & $\begin{array}{c}\text { Standard } \\
\text { Deviation }\end{array}$ & Minimum & Maximum \\
\hline TC & 37 & 2.2911 & .77187 & .66 & 3.99 \\
TRUST & 37 & 29.3378 & 19.30408 & 1.90 & 69.50 \\
POWER & 37 & 33.8649 & 10.73458 & 13.00 & 65.00 \\
\hline
\end{tabular}

Note: $\mathrm{N}=37$ list-wise

The TC scores range from 0.66 to 3.99. TC mean score of 2.2911 is considered above average, since it is more than $50 \%$ of 3.99 , meaning that TC among African countries is higher than average. The TRUST scores range from 1.9 to 69.50 . Thus, TRUST mean score of 29.3378 is considered low, since it is less than $50 \%$ of 69.50 . This implies that TRUST in authorities among African countries is less than average. The POWER scores range from 13 to 65 . The mean score for POWER of 33.8649 is considered above average, since it is more than $50 \%$ of 65.00. This implies that POWER of authorities is above average for Sub-Saharan Africa.

Table 3: Pearson Correlation

\begin{tabular}{cccc}
\hline Variables & TC & TRUST & POWER \\
\hline TC & 1.000 & $0.298 ; 0.037^{* *}$ & $0.361 ; 0.014^{* *}$ \\
TRUST & - & 1.000 & $0.849 ; 0.000^{*}$ \\
POWER & - & - & 1.000 \\
\hline
\end{tabular}

Note: $*$ significant at $0.001 ; * *$ significant at 0.05

Table 4: Regression Analysis

\begin{tabular}{cc}
\hline Independent Variable & Statistics \\
\hline Constant & $0.008(2.829)^{*}$ \\
Power & $0.920(-0.101)$ \\
Trust & $0.210(1.277)$ \\
$\mathrm{R}^{2}$ & $13 \%$ \\
$\mathrm{R}^{2}$ Adjusted & $7.9 \%$ \\
$\mathrm{~F}$ & $2.547^{* *}$ \\
F test significance & $0.093^{* *}$ \\
\hline
\end{tabular}

Note: Dependent Variable: TC; *Significant at $\alpha=0.01 ; * *$ Significant at $\alpha=0.10$ 
Pearson correlation analysis in Table 3 was used to test Hypotheses 1 to 3 above, whereas regression analysis in Table 4 served as a basis for testing Hypothesis 4 .

In Table 3, the result of the Pearson correlation shows that the correlation between TRUST and TC is positive and significant (Pearson $=0.298, p=0.037$ ). This supports Hypothesis 1 which postulates that there is a significantly positive correlation between trust in authorities and tax compliance. This is consistent with previous studies (Kastlunger, et al., 2013; Kirchler, Hofmann, \& Gangl, 2012; Kogler, et al., 2012; Muehlbacher, Kirchler, \& Schwarzenberger, 2011; van Dijke \& Verboon, 2010; Wahl, et al., 2010) which confirm the association of trust in authorities and tax compliance.

Likewise, Pearson correlation in Table 3 shows that there is a significantly positive correlation between POWER and TC (Pearson $=0.361, p=0.014$ ). This also confirms the Hypothesis that power of authorities has a significantly positive correlation with tax compliance, consistent with prior research on the association of power of authorities and tax compliance (Kastlunger, et al., 2013; Kirchler, et al., 2012; Kogler, et al., 2012; Muehlbacher, et al., 2011; van Dijke \& Verboon, 2010; Wahl, et al., 2010).

Additionally, it can be deduced from the Pearson correlation analysis in Table 3 that the significantly positive correlation between POWER and TC is higher than that of TRUST and TC. This is contrary to our postulation that TRUST has a more significantly positive correlation with TC than POWER. The result shows that the correlation between POWER and TC is higher (Pearson $=0.361, p=0.014$ ) than that of TRUST and POWER (Pearson $=0.298, p=0.037)$. This does not support Hypothesis that trust in authorities has a more significantly positive correlation with tax compliance than power of authorities. The essence of this hypothesis is to test which of the two elements of the Slippery Slope Framework is more correlated to tax compliance so as to highlight policy insights to African policymakers. By implication, power of authorities better explains compliance than trust in authorities in Sub-Saharan Africa. This finding is consistent with the assertion of Fjeldstad (2001) who posited that tax revenue performance in some African countries depends on the degree of coercive power associated with tax enforcement.

In Table 4, the regression analysis shows neither POWER ( $t=-101, p=0.92)$ nor TRUST ( $t=$ $1.277, p=0.21$ ) has significant causing effect on TC in Sub-Saharan Africa using cross-country data. The regression analysis above analyses depicts significant level of reliability based on similar studies (Riahi-Belkaoui, 2004; Richardson, 2006).

\section{CONCLUSION}

The study examines the effect of trust in authorities and power of authorities on tax compliance using cross-country data for Sub-Saharan Africa. The result from statistical analysis implies the need for African countries to be committed to increasing the level of trust citizens have on the government; more specifically, tax authorities and officials. Central and state governments should ensure the provision of high quality of services and building qualitative infrastructures with taxpayers' money which in essence will increase the level of trust citizens have for the authorities. It is hoped that the result from this study can help increase tax compliance. 
Corrupt practices among tax officials should also be curtailed in order to enhance taxpayers' compliance. Another implication of the study is the need for increased use of power by the government. Specifically, the use of power by tax authorities may be able to enhance tax compliance. Increasing power of detection and penalty could be among the measures SubSaharan Africa countries can employ to enhance tax compliance. Compared to the two measures of trust and power, increased power seems to be a greater requirement as highlighted by the statistical results.

We recommend future studies to use panel data in Sub-Saharan Africa, i.e., for a number of years across countries so as to ensure the findings can hold overtime. We also recommend using this approach for other countries so as to further test the assumptions of the "Slippery Slope Framework" using cross-country analysis. Using panel data in other continents in testing the Framework's assumptions is also recommended.

\section{ACKNOWLEDGEMENT}

Authors received no funding for the conduct of this research. They are immensely grateful to the anonymous reviewers for their valuable comments.

\section{REFERENCES}

Allingham, M. G., \& Sandmo, A. (1972). Income Tax Evasion: A Theoretical Analysis Journal of Public Economics, 1(1972), 323-338.

Alm, J. (1999). Tax compliance and administration. Public Administration and Public Policy, 72, 741-768.

Carter, A., \& Cebreiro, A. (2011). Africa's tax system: A survey OECD Observer (Vol. 284). OECD Centre for Tax Policy and Administration.

Central Intelligence Agency. (2012). World Facts Book. Retrieved April 7, 2013, from https:// www.cia.gov/library/publications/the-world-factbook/geos/ni.html

Chow, C. Y. (2004). Gearing up for the self assessment tax regime for individuals. Tax Nasional (2nd quarter), 20-23.

Cobham, A. (2005). Tax evasion, tax avoidance and development finance. Queen Elizabeth House Working Paper Number 129.

Feld, L. P., \& Frey, B. S. (2007). Tax compliance as the result of a psychological tax contract: The role of incentives and responsive regulation. Law \& Policy, 29(1), 102-120.

Fjeldstad, O.-H. (2001). Taxation, coercion and donors: local government tax enforcement in Tanzania. The Journal of Modern African Studies, 39(02), 289-306.

Government Accountability Office. (2012). Federal Tax Debt: Factors for Considering a Proposal to Report Tax Debts to Credit Bureaus. In J. R. White (Eds.), Report to Congressional Requesters. Washington, DC. 
International Monetary Fund. (2011). Revenue Mobilization in Developing Countries. Washington DC: International Monetary Fund.

Jackson, B. R., \& Milliron, V. C. (1986). Tax compliance research: Findings, problems, and prospects. Journal of Accounting Literature, 5(1), 25-65.

Kastlunger, B., Lozza, E., Kirchler, E., \& Schabmann, A. (2013). Powerful authorities and trusting citizens: The Slippery Slope Framework and tax compliance in Italy. Journal of Economic Psychology, 34(0), 36-45. doi: http://dx.doi.org/10.1016/j.joep.2012.11.007

Kaufmann, D., Kraay, A., \& Mastruzzi, M. (2010). The Worldwide Governance Indicators: Methodology and Analytical Issues. World Bank Policy Research Working Paper No. 5430. Retrieved from SSRN: http://ssrn.com/abstract=1682130

Kim, S. (2008). Does political intention affect tax evasion? Journal of Policy Modeling, 30(3), 401-415. doi: http://dx.doi.org/10.1016/j.jpolmod.2007.12.004

Kirchler, E., Hoelzl, E., \& Wahl, I. (2008). Enforced versus voluntary tax compliance: The "slippery slope" framework. Journal of Economic Psychology, 29(2), 210-225.

Kirchler, E., Hofmann, E., \& Gangl, K. (2012). From mistrusting taxpayers to trusting citizens: Empirical evidence and further development of the Slippery Slope Framework. In A. N. Lebedev (Ed.), Economic psychology in the modern world. Collected papers. Moscow: Ekon-inform.

Kogler, C., Batrancea, L., Nichita, A., Pántya, J., Belianin, A., \& Kirchler, E. (2012). Trust and Power as Determinants of Tax Compliance: Testing the Assumptions of the Slippery Slope Framework in Austria, Hungary, Romania and Russia. Journal of Economic Psychology, 34, 169-180.

Loo, E. C. (2006). Influence of the introduction of self assessment on the compliance behavior of individual taxpayers in Malaysia. (Doctoral Dissertation, The University of Sydney).

Muehlbacher, S., Kirchler, E., \& Schwarzenberger, H. (2011). Voluntary versus enforced tax compliance: empirical evidence for the "slippery slope" framework. European Journal of Law and Economics, 32(1), 89-97.

Palil, M. R., \& Mustapha, A. F. (2011). Factors affecting tax compliance behaviour in self assessment system. African Journal of Business Management, 5(33), 12864-12872.

Pellizzari, P., \& Rizzi, D. (2014). Citizenship and power in an agent-based model of tax compliance with public expenditure. Journal of Economic Psychology, 40(February), $35-48$.

Ramona-Anca, N., \& Larissa-Margareta, B. (2012). The Implications Of Tax Morale On Tax Compliance Behavior. Annals of Faculty of Economics, 1(1), 739-744.

Riahi-Belkaoui, A. (2004). Relationship between tax compliance internationally and selected determinants of tax morale. Journal of International Accounting, Auditing and Taxation, 13(2), 135-143. doi: http://dx.doi.org/10.1016/j.intaccaudtax.2004.09.001 
Richardson, G. (2006). Determinants of tax evasion: A cross-country investigation. Journal of International Accounting, Auditing and Taxation, 15(2), 150-169. doi: http://dx.doi. org/10.1016/j.intaccaudtax.2006.08.005

Sabirianova, P. K., Buttrick, S., \& Duncan, D. (2009). Global reform of personal income taxation, 1981-2005: Evidence from 189 countries. Andrew Young School of Policy Studies Research Paper Series(08-08).

Silvani, C., \& Baer, K. (1997). Designing a tax administration reform strategy: experiences and guidelines. IMF Working Paper WP/97/30.

Srinivasan, T. N. (1973). Tax evasion: A model. Journal of public economics, 2(4), 339-346.

Terkper, S. (13 January, 2003). Managing small and medium size taxpayers in developing economies. Tax Note International, 211-234.

Torgler, B., \& Schneider, F. (2009). The impact of tax morale and institutional quality on the shadow economy. Journal of Economic Psychology, 30(2), 228-245. doi: http://dx.doi. org/10.1016/j.joep.2008.08.004

Torgler, B., Demir, I. C., Macintyre, A., \& Schaffner, M. (2008). Causes and consequences of tax morale: An empirical investigation. Economic Analysis and Policy (EAP), 38(2), 313-339.

Torgler, B., Schaffner, M., \& Macintyre, A. (2007). Tax compliance, tax morale, and governance quality. CREMA Working Paper Series 2007-17.

Transparency International. (2012). Corruption Perception Index 2012. Retrieved May 26, 2013, from http://www.transparency.org/cpi2012

van Dijke, M., \& Verboon, P. (2010). Trust in authorities as a boundary condition to procedural fairness effects on tax compliance. Journal of Economic Psychology, 31(1), 80-91. doi: http://dx.doi.org/10.1016/j.joep.2009.10.005

Wahl, I., Kastlunger, B., \& Kirchler, E. (2010). Trust in Authorities and Power to Enforce Tax Compliance: An Empirical Analysis of the "Slippery Slope Framework". Law \& Policy, 32(4), 383-406.

World Bank Group. (2012). Worldwide Governance Indicators. Retrieved June 7, 2013, from http://info.worldbank.org/governance/wgi/index.aspx\#home

World Bank Group. (2012). Worldwide Governance Indicators. Retrieved July 11, 2013, from http://data.worldbank.org/data-catalog/worldwide-governance-indicators 


\section{APPENDIXES}

\section{Descriptive Statistics}

\begin{tabular}{cccccc}
\hline & N & Minimum & Maximum & Mean & Std. Deviation \\
\hline TC & 37 & .66 & 3.99 & 2.2911 & .77187 \\
TRUST & 37 & 1.90 & 69.50 & 29.3378 & 19.30408 \\
POWER & 37 & 13.00 & 65.00 & 33.8649 & 10.73458 \\
Valid N (listwise) & 37 & & & & \\
\hline
\end{tabular}

\begin{tabular}{cccc}
\multicolumn{4}{c}{ Correlations } \\
\hline \multirow{2}{*}{ TC } & TC & TRUST \\
& Pearson Correlation & 1 & $.298^{*}$ \\
& Sig. (1-tailed) & & .037 \\
& $\mathrm{~N}$ & 37 & 37 \\
\hline \multirow{2}{*}{ TRUST } & Pearson Correlation & $.298^{*}$ & 1 \\
& Sig. (1-tailed) & .037 & \\
& $\mathrm{~N}$ & 37 & 37 \\
\hline
\end{tabular}

Note: *. Correlation is significant at the 0.05 level (1-tailed).

\section{Correlations}

\begin{tabular}{cccc}
\hline & & TC & POWER \\
\hline TC & Pearson Correlation & 1 & $.361^{*}$ \\
& Sig. (1-tailed) & & .014 \\
& $\mathrm{~N}$ & 37 & 37 \\
\hline POWER & Pearson Correlation & $.361^{*}$ & 1 \\
& Sig. (1-tailed) & .014 & \\
& $\mathrm{~N}$ & 37 & 37 \\
\hline
\end{tabular}

Note: *. *. Correlation is significant at the 0.05 level (1-tailed).

Variables Entered/Removed ${ }^{\mathrm{b}}$

\begin{tabular}{cccc}
\hline Model & Variables Entered & Variables Removed & Method \\
\hline 1 & POWER, TRUST & $\cdot$ & Enter \\
\hline
\end{tabular}

Note: a. All requested variables entered.

b. Dependent Variable: TC

Model Summary ${ }^{\mathrm{b}}$

\begin{tabular}{ccccc}
\hline Model & R & R Square & $\begin{array}{c}\text { Adjusted } \\
\text { R Square }\end{array}$ & $\begin{array}{c}\text { Std. Error of } \\
\text { the Estimate }\end{array}$ \\
\hline 1 & $.361 \mathrm{a}$ & .130 & .079 & .74069 \\
\hline
\end{tabular}

Note: a. Predictors: (Constant), POWER, TRUST

b. Dependent Variable: TC 
ANOVA $^{\mathrm{b}}$

\begin{tabular}{ccccccc}
\hline & Model & Sum of Squares & Df & Mean Square & F & Sig. \\
\hline 1 & Regression & 2.795 & 2 & 1.397 & 2.547 & $.093 \mathrm{a}$ \\
& Residual & 18.653 & 34 & .549 & & \\
& Total & 21.448 & 36 & & & \\
\hline
\end{tabular}

Note: $\quad$ a. Predictors: (Constant), POWER, TRUST

b. Dependent Variable: TC

\section{Coefficients $^{\mathrm{a}}$}

\begin{tabular}{ccccccc}
\hline \multirow{2}{*}{ Model } & \multicolumn{2}{c}{$\begin{array}{c}\text { Unstandardized } \\
\text { Coefficients }\end{array}$} & $\begin{array}{c}\text { Standardized } \\
\text { Coefficients }\end{array}$ & \multirow{2}{*}{ T } & Sig. \\
\cline { 3 - 5 } & B & Std. Error & Beta & & \\
\hline 1 & (Constant) & 1.386 & .490 & & 2.829 & .008 \\
& POWER & -.001 & .012 & -.031 & -.101 & .920 \\
& TRUST & .028 & .022 & .387 & 1.277 & .210 \\
\hline
\end{tabular}

Note: $\quad$ a. Dependent Variable: TC

Residuals Statistics ${ }^{\mathrm{a}}$

\begin{tabular}{cccccc}
\hline & Minimum & Maximum & Mean & Std. Deviation & $\mathbf{N}$ \\
\hline Predicted Value & 1.7435 & 3.1075 & 2.2911 & .27863 & 37 \\
Std. Predicted Value & -1.965 & 2.930 & .000 & 1.000 & 37 \\
Standard Error of Predicted Value & .123 & .389 & .200 & .068 & 37 \\
Adjusted Predicted Value & 1.7787 & 3.1464 & 2.2947 & .29019 & 37 \\
Residual & -1.29407 & 1.81228 & .00000 & .71983 & 37 \\
Std. Residual & -1.747 & 2.447 & .000 & .972 & 37 \\
Stud. Residual & -1.802 & 2.545 & -.002 & 1.013 & 37 \\
Deleted Residual & -1.37640 & 1.96132 & -.00360 & .78279 & 37 \\
Stud. Deleted Residual & -1.866 & 2.787 & .009 & 1.048 & 37 \\
Mahal. Distance & .018 & 8.937 & 1.946 & 2.096 & 37 \\
Cook's Distance & .000 & .178 & .029 & .045 & 37 \\
Centered Leverage Value & .000 & .248 & .054 & .058 & 37 \\
\hline
\end{tabular}

Note: a. Dependent Variable: TC
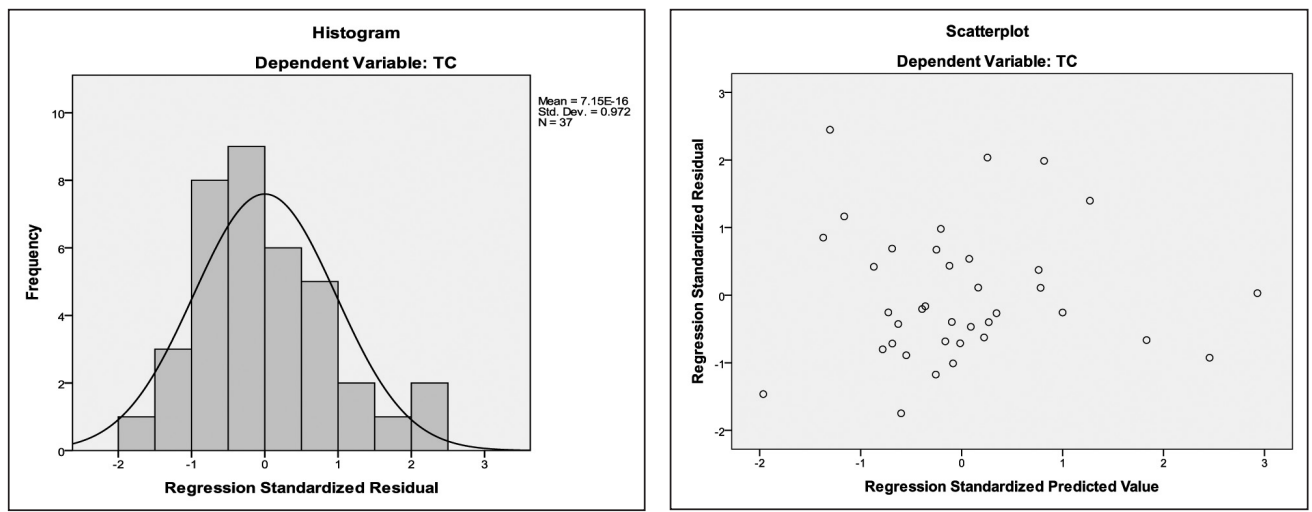